\title{
MEDICINAL PLANTS OF SELECTED WETLANDS IN PANNISSERY AREA, THRISSUR DISTRICT, KERALA-A PRELIMINARY SURVEY
}

\author{
K. R. ATHIRA ${ }^{1}$ \\ ${ }^{1}$ Guest Lecturer, Department of Botany, Sreekrishna College, Guruvayur, Thrissur, Kerala, India \\ Email: athirakramachandran37@gmail.com
}

Received: 14 May 2019, Revised and Accepted: 15 Jul 2019

\section{ABSTRACT}

Objective: Wetlands are vital ecosystem which provides livelihoods for millions of people who live within around them. Man depends on wetlands for most of his needs from time immemorial. The present study is a preliminary step for the identification of valuable medicinal plants in the wetlands of Pannissery area. This attempt was made since it is equally important to understand the traditional medicines and beliefs as well as to have scientific awareness for protection and conservation of the sewetlands.

Methods: Frequent field visits were carried out from September 2018 to January 2019 to collect different Wetland medicinal plants in Pannissery area, Kandanassery Panchayath, Thrissur district. Plants were collected carefully with hand and identified by using the standard literature such as Flora of the Presidency of Madras by J. S. Gamble, 1915-1936. The collected plants were authenticated by a plant Taxonomist Dr. Udayan. P. S. from the Post Graduate and Research Department of Botany, Sree Krishna College, Guruvayur.

Results: A slight alteration of the wetland may result in the disappearance or the extinction of these plants [1].

Conclusion: This will ultimately result in large scale economic loss in terms of the medicinal product. Apart from the loss of plants, this will also result in the loss of local knowledge on the medicinal properties of these plants which very often can't be retrieved. An attempt has been made to document some of the little known medicinal properties of wetland plants used by local community.

Keywords: Wetland, Ecosystem, Medicinal plants,Wetland plants, Pharmaceutical industry

(C) 2019 The Authors. Published by Innovare Academic Sciences Pvt Ltd. This is an open-access article under the CC BY license (http://creativecommons.org/licenses/by/4.0/) DOI: http://dx.doi.org/10.22159/ijcpr.2019v11i5.35709

\section{INTRODUCTION}

India has rich wealth of important medicinal flora and its varied climate is ideally suited for the cultivation of medicinal plants. Quality of the plant derived medicine is a matter of great concerns as the utilization of plant materials for cure of infections and chronic human diseases is increasing. One of the oldest repositories of human knowledge, the Rig-Veda (4500-4600BC) mentioned the use of medicinal plants for the treatment of one or other disease [2]. Ethnomedicinal uses of 48 wetland plant species of South Orissa and discussed their conservation [3]. The present work reviews the utilities of wetland plant species as medicine with the help of authentic publications and by the incorporation of traditional knowledge of local communities in this aspect. Wetlands cover approximately $5 \%-8 \%$ of the global land area. A wetland is a land area that is saturated with water, either permanently or seasonally, such that it takes on the characteristics of a distinct ecosystem. Ramsar Convention defines wetlands as "areas of marsh, fen, peatland or water, whether natural or artificial, permanent or temporary, with water that is static or flowing, fresh, brackish or salt, including areas of marine water the depth of which at low tide does not exceed six metres". Wetlands provide a unique habitat for several medicinal plants. In spite of their commercial value, the local community utilizes a good number of these plants for various curative purposes. A number of these plants are very sensitive to the fluctuation in the normal physic-chemical parameter of the wetland. A slight alteration of the wetland may result in the disappearance or the extinction of these plants ${ }^{1}$. This will ultimately result in large scale economic loss in terms of the medicinal product. Apart from the loss of plants, this will also result in the loss of local knowledge on the medicinal properties of these plants which very often can't be retrieved. An attempt has been made to document some of the little known medicinal properties of wetland plants used by local community.

\section{MATERIALS AND METHODS}

Frequent field visits were carried out from September 2018 to January 2019 to collect different Wetland medicinal plants in Pannissery area, Kandanassery Panchayath, Thrissur district. Plants were collected carefully with hand and identified by using the standard literature such as Flora of the Presidency of Madras by J. S. Gamble, 1915-1936. The collected plants were authenticated by a plant Taxonomist Dr. Udayan. P. S. from the Post Graduate and Research Department of Botany, Sree Krishna College, Guruvayur. The collected specimen was dried properly and preserved in the herbarium sheet.

\section{RESULTS}

Table 1: List of medicinal plants

\begin{tabular}{|c|c|c|c|c|}
\hline S. No. & Name and family & Local name & Parts used & Uses \\
\hline 1. & $\begin{array}{l}\text { Acmellacalva (D. C) } \\
\text { R. K. Jansen Asteraceae }\end{array}$ & Panibisalyakarani & Flower head & $\begin{array}{l}\text { Its flower heads were typically applied to treat and cure } \\
\text { stammering in Children. }\end{array}$ \\
\hline 2. & $\begin{array}{l}\text { Alternanthera bettzickiana } \\
\text { (Regel) voss. Amaranthaceae }\end{array}$ & Calico plant & $\begin{array}{l}\text { Leaves and } \\
\text { Young shoots }\end{array}$ & $\begin{array}{l}\text { The whole plant is reported to be useful in purifying and } \\
\text { nourishing blood. }\end{array}$ \\
\hline 3. & CentellaasiaticaL. Apiaceae & Brahmnibuti & Whole plant & $\begin{array}{l}\text { The leaves are useful in abdominal disorders due to } \\
\text { dysentery in children. }\end{array}$ \\
\hline 4. & Cleome rutidosperma & Fringed spider & Whole plant & A decoction is used to treat malaria. \\
\hline
\end{tabular}




\begin{tabular}{|c|c|c|c|c|}
\hline & DC. Cleomaceae & flower & & \\
\hline 5. & $\begin{array}{l}\text { Colocasia esculenta } \\
\text { (Linn.) schott. araceae }\end{array}$ & Taro & $\begin{array}{l}\text { Leaves and } \\
\text { corms }\end{array}$ & $\begin{array}{l}\text { The leaf juice is styptic, stimulant and rubefacient and is } \\
\text { useful in internal haemorrhages. }\end{array}$ \\
\hline 6. & $\begin{array}{l}\text { Cyclea peltata (Lam.) Hook. f. } \\
\text { and Thoms. Menispermaceae }\end{array}$ & Padathali & $\begin{array}{l}\text { Roots } \\
\text { And leaves }\end{array}$ & $\begin{array}{l}\text { The leaves are cooling and ophthalmic and are useful in } \\
\text { dandruff, burning sensation of the eye and fever and are used } \\
\text { in the place of soap. }\end{array}$ \\
\hline 7. & $\begin{array}{l}\text { Cynodon dactylon } \\
\text { (Linn.) Pers. Poaceae }\end{array}$ & Bermuda grass & Whole plant & $\begin{array}{l}\text { The plant is astringent, sweet, cooling, haemostatic, } \\
\text { depurative, vulnerary, constipating, diuretic and tonic. }\end{array}$ \\
\hline 8. & $\begin{array}{l}\text { Cyperus tenuispica } \\
\text { Steud. Cyperaceae }\end{array}$ & $\begin{array}{l}\text { Slenderspiked } \\
\text { sedge }\end{array}$ & Rhizome & $\begin{array}{l}\text { Tuber paste is used as an appetizer and also used for skin } \\
\text { diseases. }\end{array}$ \\
\hline 9. & $\begin{array}{l}\text { Datura stramonium } \\
\text { L. Solanaceae }\end{array}$ & Ummam & $\begin{array}{l}\text { Leaves and } \\
\text { seeds }\end{array}$ & $\begin{array}{l}\text { The fruit juice is applied to the scalp for the treatment of } \\
\text { falling hair and dandruff. }\end{array}$ \\
\hline 10. & $\begin{array}{l}\text { Desmodium triflorum (L.)DC. } \\
\text { Fabaceae }\end{array}$ & Black clover & Whole plant & $\begin{array}{l}\text { The whole plant is used medicinally for inducing sweat and } \\
\text { promoting digestion. }\end{array}$ \\
\hline 11. & $\begin{array}{l}\text { Eclipta prostrata } \\
\text { (Linn.) Linn. Asteraceae }\end{array}$ & Bhringaraj & Whole Plant & It is good for blackening and strengthening of hair \\
\hline 12. & $\begin{array}{l}\text { Heliotropiumindicum } \\
\text { L. Boraginaceae }\end{array}$ & Indian heliotrope & $\begin{array}{l}\text { Leaves,roots } \\
\text { and seeds }\end{array}$ & Leaf extract is used in insect bites. \\
\hline 13. & $\begin{array}{l}\text { Hygrophila schulli } \\
\text { (Buch.-Ham.) M. R. and S. M. } \\
\text { Almeida Acanthaceae }\end{array}$ & Vayalchulli & Whole plant & The leaves are used in jaundice, rheumatism and dysentery. \\
\hline 14. & $\begin{array}{l}\text { Leucas aspera (Willd.) Link. } \\
\text { Lamiaceae }\end{array}$ & Thumbai & $\begin{array}{l}\text { Leaves and } \\
\text { flowers }\end{array}$ & $\begin{array}{l}\text { The juice of leaves are useful as a nasal drop in catarrh and } \\
\text { cephalalgia. }\end{array}$ \\
\hline 15. & $\begin{array}{l}\text { Ludwigiahyssopifolia } \\
\text { (G. Don)Exell. Onagraceae }\end{array}$ & Water primose & Whole plant & The leaves are used in febrifuge decoction. \\
\hline
\end{tabular}
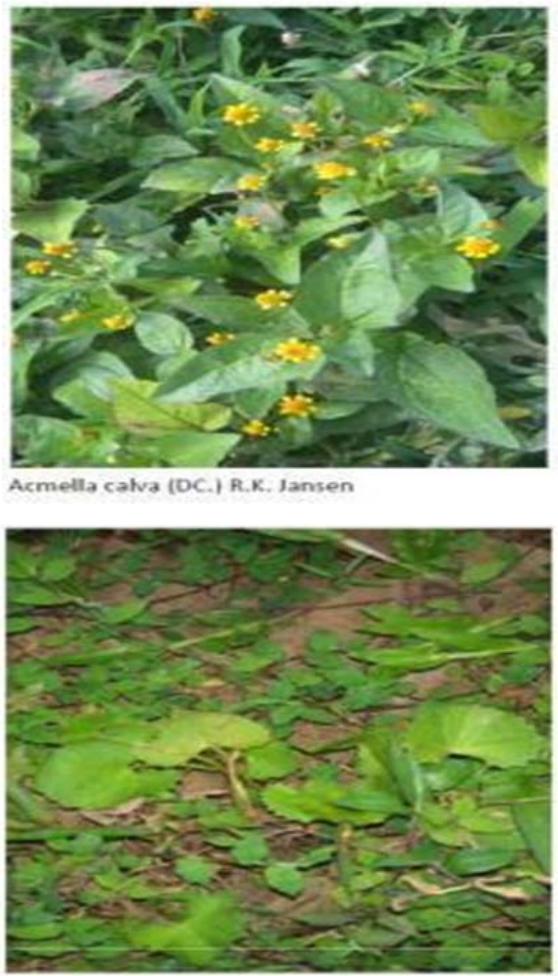

Centella asiatica Urban

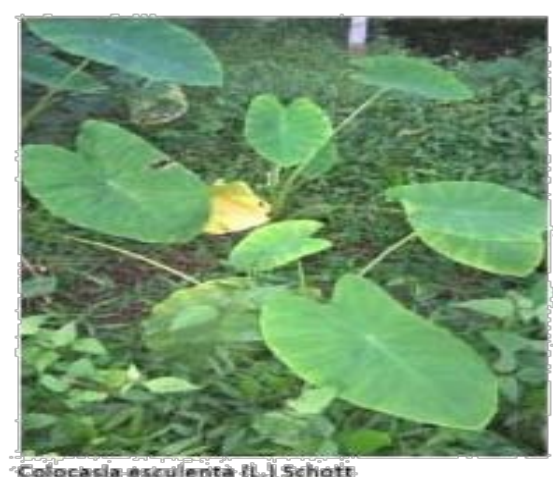

Colocasia escul enta RLi Schot:

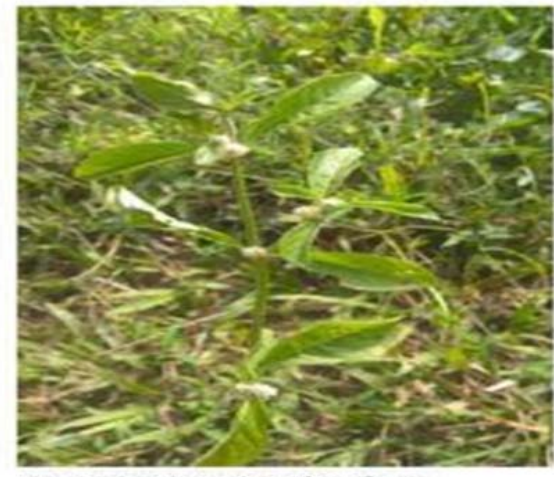

Alternanthers bettaickians (Recel) Voss

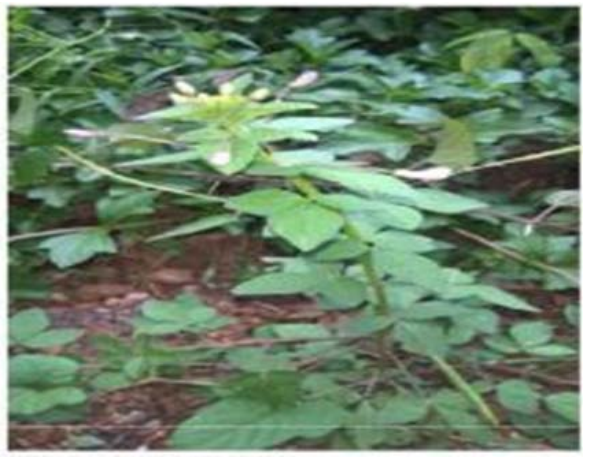

Cleome rutidosperma DC.

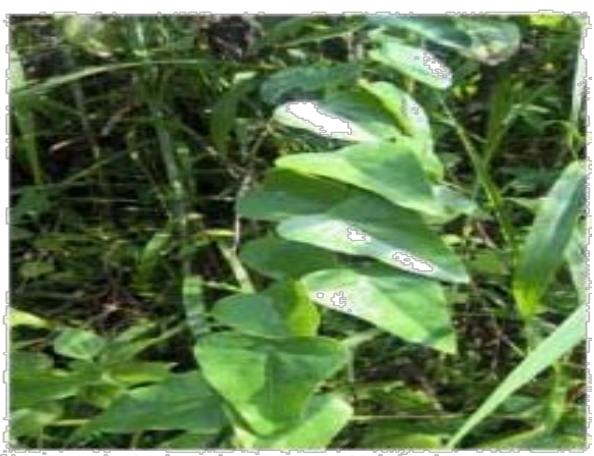

Cycieg peltata flaing Hoic if \& Thoings 


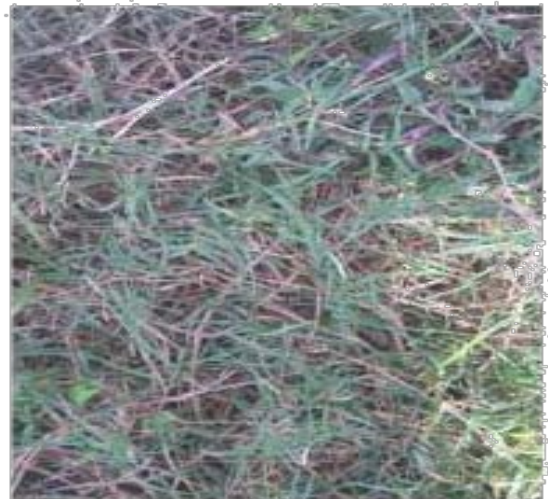

Cynodon dactylon (L) Pers.

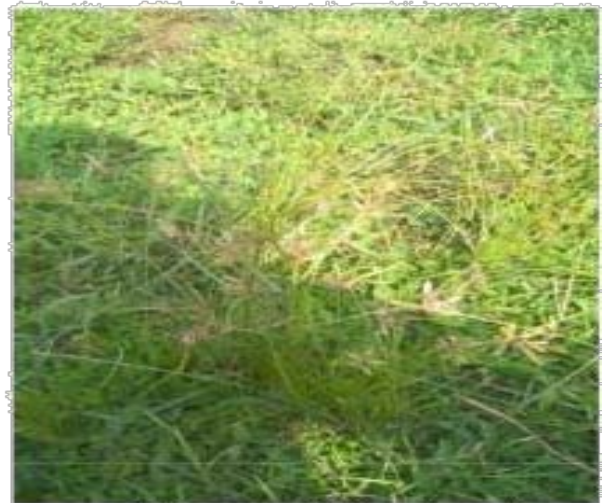

Cypericts tenulspicasteud:

Fig. 1: Common wetland medicinal plants seen in Pannissery area

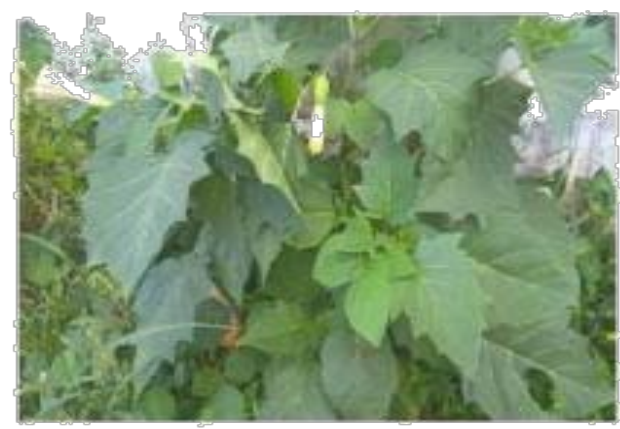

Datúra ktrachoniumil:

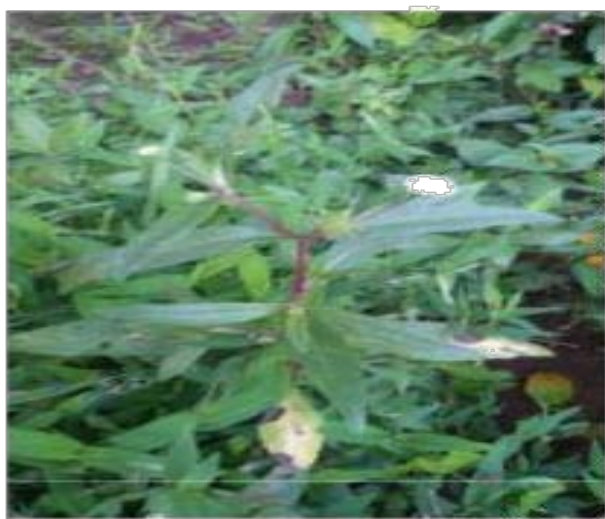

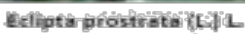

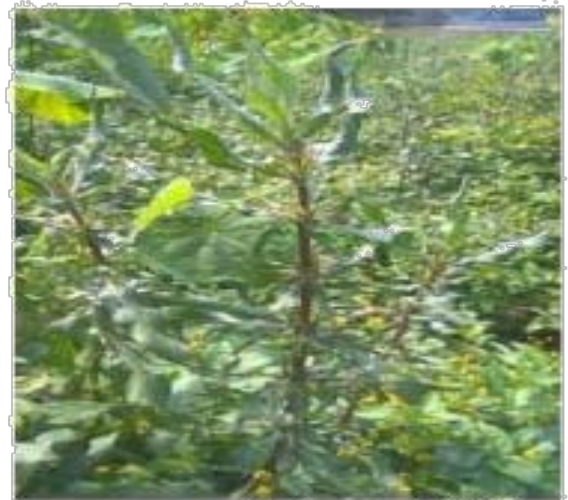

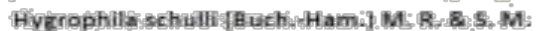
Almeida

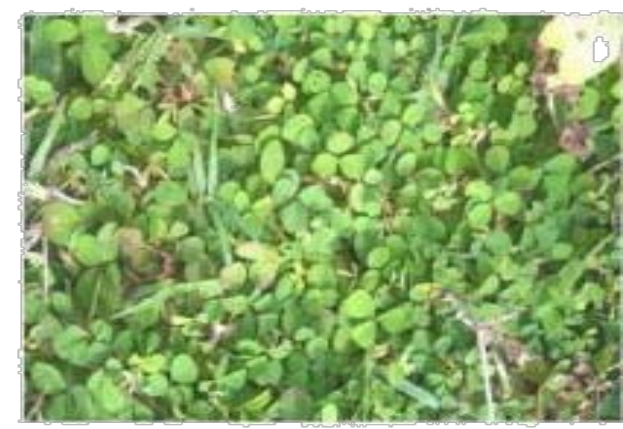

Desmodium thifotium itu $\mathrm{DC}$.

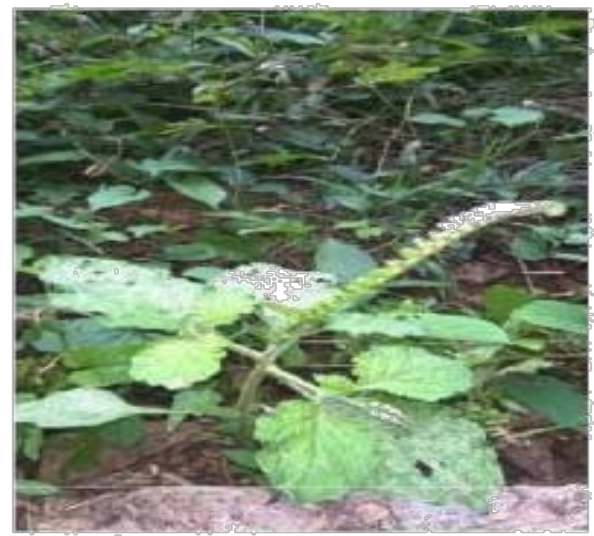

Helilotropium inidictuin t.

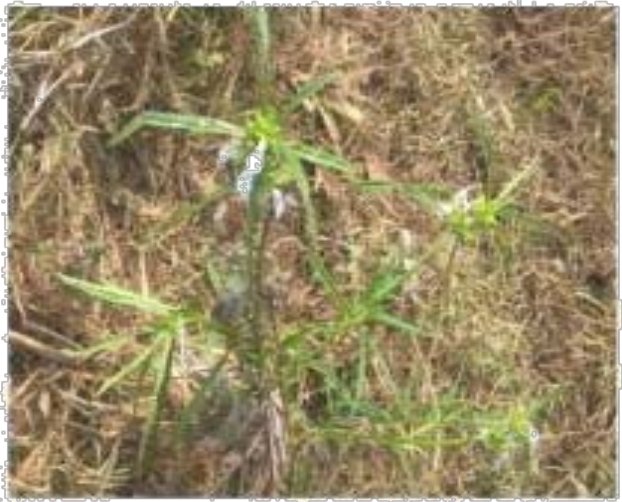

feurcas aspera (Willd ILink 


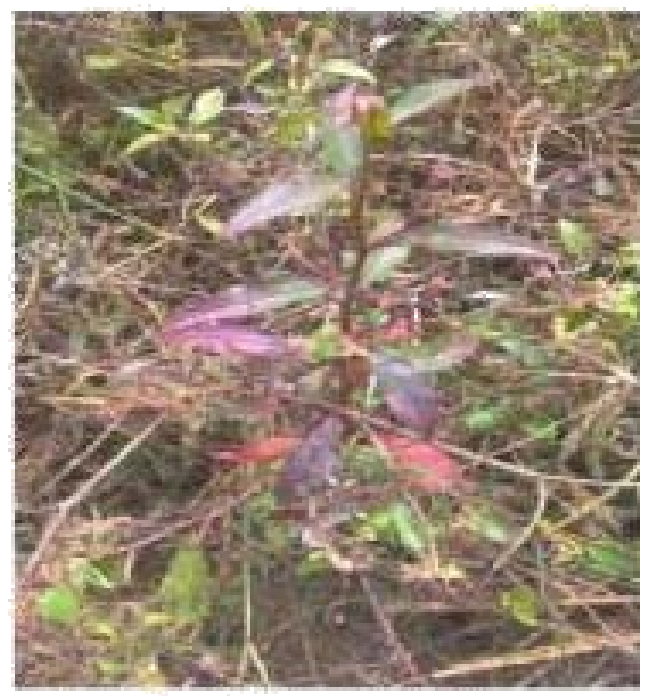

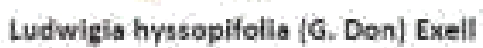

Fig. 2: Common wetland medicinal plants seen in Pannissery area

\section{DISCUSSION}

The present study showed that family Fabaceae occupy the first position followed by Poaceae and Solanaceae. In the study area the flora showed 16 Herbs (64\%); 9 Shrubs (36\%). Alternantherabettzickiana and Mimosa pudicaare the invasive plants found in the study area. These weeds are the indication of the disturbance in the vegetation of the area. Hygrophyllaschulli, Mimosa pudica, Ludwigiahyssopifolia, Colocassia esculenta, Oryza sativa, Desmodium trifolium and Cyperustenuispica are the dominating species. The identified plants belonged to different families and maximum number of plants were found to be coming under the family Fabaceae, Solanaceae and Poaceae. Out of 17500 flowering plant species known from India,more than 4000 species are used as medicinal plants ${ }^{4}$. Overexploitation and indiscriminate use of wild resources in commercial demand acting as the major factors in disturbing the entire ecosystem. Destruction of wetlands is mainly due to the intrusion of non-native Kspecies, draining wetlands for agricultural purposes and mosquito control, dikes and dams to form ponds and lakes, pollution from landfills, water pollution, pesticide usage, removal of vegetation, land pollution, air pollution etc [5] wetlands are providing a key link in watershed management, protects water quality, controls flooding, serves as home for many plants and animals, and providing various types of medicinal plants. There are various efforts to conserve wetlands. They are various nature conservancy proposes mainly rehabilitation, construction of new wetlands; minimize damage to wetlands, Conservation of wetland flora and fauna [4].

While considering the importance of ethnobotanical studies it should be remembered that many times the natives do not like to share their knowledge with others. Also, for majority of the diseases it so happens that not a single plant is administered but is given in combination with many plant parts, all of which again may not be encountered in a particular field trip [6]. Sometimes, the same plant is suggested for more than one disease. In such cases it is very difficult to assess which plant is actually effective in curing a particular disease [7]. Only clinical trials on these plants can give some indications. The wetlands affect water quality through nutrient cycling, sediment deposition, ion and molecular absorption and temperature modification [8].

\section{CONCLUSION}

The present study is a preliminary step for the identification of valuable medicinal plants in the wetlands of Pannissery area. This attempt was made since it is equally important to understand the traditional medicines and beliefs as well as to have scientific awareness for protection and conservation of these wetlands.
Increased demand for plant-derived drugs is putting pressure on high value medicinal plants and risking their biodiversity. Increasing populations, urbanization and deforestation are contributing to species endangerment in developing countries. The flora is the most important factor to maintain the biodiversity of an area. The decrease or elimination of medicinal plants is increasing due to overexploitation and unsustainable development. From this minor study 25 species of wetland plants belonging to 19 families were recorded to be used by the traditional medicine practitioners. These medicinal plant remedies comparatively have certain advantages, as these are easily accessible and affordable to rural community. The wetlands have a vast wealth of plants, which are sources of medicinal compounds. On the other hand loss of important floral diversity also leads to declining of it. Hence conservation of floral diversity will be important tool to sustain and carry such important knowledge to the future generation.

\section{ACKNOWLEDGMENT}

First of all I would like to show my deep sense of gratitude to the Almighty God whose unbounded ray of blessings enriched my thoughts and deeds and also gave good health, strength and selfconfidence. I feel extremely honored for the opportunities given to me to work under the supervision of Dr. Udayan. P. S. Head of the Department of Botany, Sreekrishna College Guruvayur, Thrissur, for the continuous and valuable guidance and unstained encouragement through the course of these theses. My special thanks to the concerned authority of librarians of Sreekrishna College Guruvayur, Kerala Forest Research Institute (KFRI) Peechi, Kerala Agricultural University Central Library, Mannuthy, for my literature collection.

\section{AUTHORS CONTRIBUTIONS}

All the author have contributed equally

\section{CONFLICT OF INTERESTS}

Declare none

\section{REFERENCES}

1. Santosh K, Satya N. Herbal remedies of wetlands macrophytes in India. Int J Pharma BioSci 2010;1:12-6.

2. Sharma A, Shanker C, Tyagi LK, Singh M, Rao CV. Herbal medicine for market potential in India: an overview. Acad J Plant Sci Exp J 2008;1:26-36.

3. Panda A, Misra MK. Ethnomedicinal survey of some wetland plants of South Orissa and their conservation. J Name? 2011;10:296-303.

4. Joshi SG. Medicinal plants. Oxford and IBH publishing; 2000. p. 2130. 
5. Sarmah BP, Baruah D, Bakalial B. Wetland medicinal plants in floodplains of Subansiri and Ranga River of Lakhimpur District, Assam, India. Asian J Plant Sci Res 2013;3:54-60.

6. Abraham J, Thomas TD. Antibacterial activity of medicinal plant Cyclea peltata (Lam.) Hook. f. and Thoms. Asian Pacific J Trop Disease 2012;2:S280-S284.
7. Jaiswal BS. Solanum torvum: a review of its traditional uses, phytochemistry and pharmacology. Int J Pharma BioSci 2012;3:104-11.

8. Agrawal R, Garg HK, Garg U, Singh SK. Anti-ulcer activity of Smithia conferta in various animal. J Saudi Chem Soc 2010;14:307-10. 